\title{
The MET oncogene as a therapeutical target in cancer invasive growth
}

\author{
Paolo Luraghi ${ }^{1}$, Florian Schelter ${ }^{2 \dagger}$, Achim Krüger $^{2}$ and Carla Boccaccio ${ }^{1 *}$ \\ ' Division of Experimental Clinical Molecular Oncology, IRCC - Institute for Cancer Research and Treatment, University of Turin Medical School, Candiolo, Italy \\ ${ }^{2}$ Klinikum rechts der Isar der Technischen Universität München, Institut für Experimentelle Onkologie und Therapieforschung, München, Germany
}

Edited by:

Agnès Noël, University of Liège,

Belgium

Reviewed by:

Cecile Duplaa, INSERM, France

Carine Michiels, University of Namur.

Belgium

\section{*Correspondence}

Carla Boccaccio, Division of Experimental Clinical Molecular Oncology, IRCC - Institute for Cancer Research and Treatment, University of Turin Medical School, Str. Prov. 142, 10060 Candiolo, Italy.

e-mail: carla.boccaccio@ircc.it

${ }^{\dagger}$ Present address:

Florian Schelter, DTA Oncology,

Pharma Research and Early

Development, Roche Diagnostics

$\mathrm{GmbH}$, Non-nenwald 2, 82377

Penzberg, Germany.
The MET proto-oncogene, encoding the tyrosine kinase receptor for Hepatocyte Growth Factor (HGF) regulates invasive growth, a genetic program that associates control of cell proliferation with invasion of the extracellular matrix and protection from apoptosis. Physiologically, invasive growth takes place during embryonic development, and, in post-natal life, in wound healing and regeneration of several tissues. The MET oncogene is overexpressed and/or genetically mutated in many tumors, thereby sustaining pathological invasive growth, a prerequisite for metastasis. MET is the subject of intense research as a target for small molecule kinase inhibitors and, together with its ligand HGF, for inhibitory antibodies. The tight interplay of MET with the protease network has unveiled mechanisms to be exploited to achieve effective inhibition of invasive growth.

Keywords: MET oncogene, invasion, metastasis, microenvironment, targeted therapy, proteases, antibody, small molecule kinase inhibitors

\section{THE MET TYROSINE KINASE AND THE INVASIVE GROWTH PROGRAM}

The MET proto-oncogene encodes the tyrosine kinase receptor for Hepatocyte Growth Factor (HGF), also known as Scatter Factor (SF; Giordano et al., 1989; Naldini et al., 1991). This ligand is synthesized as an inert single-chain precursor, and then converted into an active $\alpha$ - and $\beta$-chain heterodimer by extracellular proteases, including members of the blood coagulation system, such as urokinase-type plasminogen activator (uPA) and factor XII. Interestingly, HGF itself shares a high degree of homology with coagulation factors, as the $\alpha$ chain contains plasminogen-like "kringle" structural motifs, and the $\beta$ chain contains a domain homologous to serine proteases, but devoid of enzymatic activity by substitution of critical aminoacids in the catalytic site (Figure 1; for a review see Trusolino and Comoglio, 2002).

The MET receptor is synthesized as a single-chain precursor that undergoes post-translational cleavage into two disulfidelinked $\alpha$ and $\beta$ subunits. The extracellular domain contains two main regions, both involved in ligand binding. The first is the "sema domain," named after its homology with the signaling molecules semaphorins, which includes the $\alpha$ chain and an $\mathrm{N}$-terminal portion of the $\beta$ chain. The second is the "immunoglobulinlike domain," containing four disulfide-linked, loop structures (Figure 1; Gherardi et al., 2003). The intracellular domain of MET includes three functional portions with aminoacidic residues critical for modulation of signaling properties: (i) a juxtamembrane sequence including Ser ${ }^{975}$, which, upon phosphorylation, downregulates kinase activity; (ii) a catalytic region, containing
$\operatorname{Tyr}^{1234}$ and $\mathrm{Tyr}^{1235}$, which, upon receptor dimerization and transphosphorylation, upregulate kinase activity; (iii) a carboxyterminal sequence including $\mathrm{Tyr}^{1349}$ and $\mathrm{Tyr}^{1356}$ that works as a multifunctional docking site required and sufficient to recruit the core of cytoplasmic signal transducers and adaptors (Figure 1; for review see Trusolino and Comoglio, 2002; Trusolino et al., 2010).

Hepatocyte growth factor and MET control a complex biological program defined as "invasive growth" (Trusolino and Comoglio, 2002). This program coordinates cell proliferation with cell invasion, and provides protection from apoptosis usually occurring in cells removed from their physiological context. MET-driven invasive growth is a physiological program taking place during embryonic development and post-natal tissue growth and regeneration (Birchmeier and Gherardi, 1998; Boccaccio and Comoglio, 2006; Trusolino et al., 2010).

The signaling pathways that couple MET activation with the invasive growth biological program are largely shared with other growth factor receptors, and include in the first place MAP Kinase and PI-3 Kinase-AKT pathways, but also STAT3, p38, and NF-kB pathways. However, as compared with other growth factor receptors, MAP kinase and PI-3 Kinase are usually activated by MET with greater intensity and duration. The ability of MET to hyperactivate PI-3 kinase and MAPK signaling is thought to be essential for the pro-invasive activity. This hyperactivation results from aggregation of a complex signaling platform that amplifies the biochemical input, and translates it into specific biological outcomes. This platform includes the intracellular docking protein Gab1, and several cell surface proteins such as: (i) CD44v6, required to link 

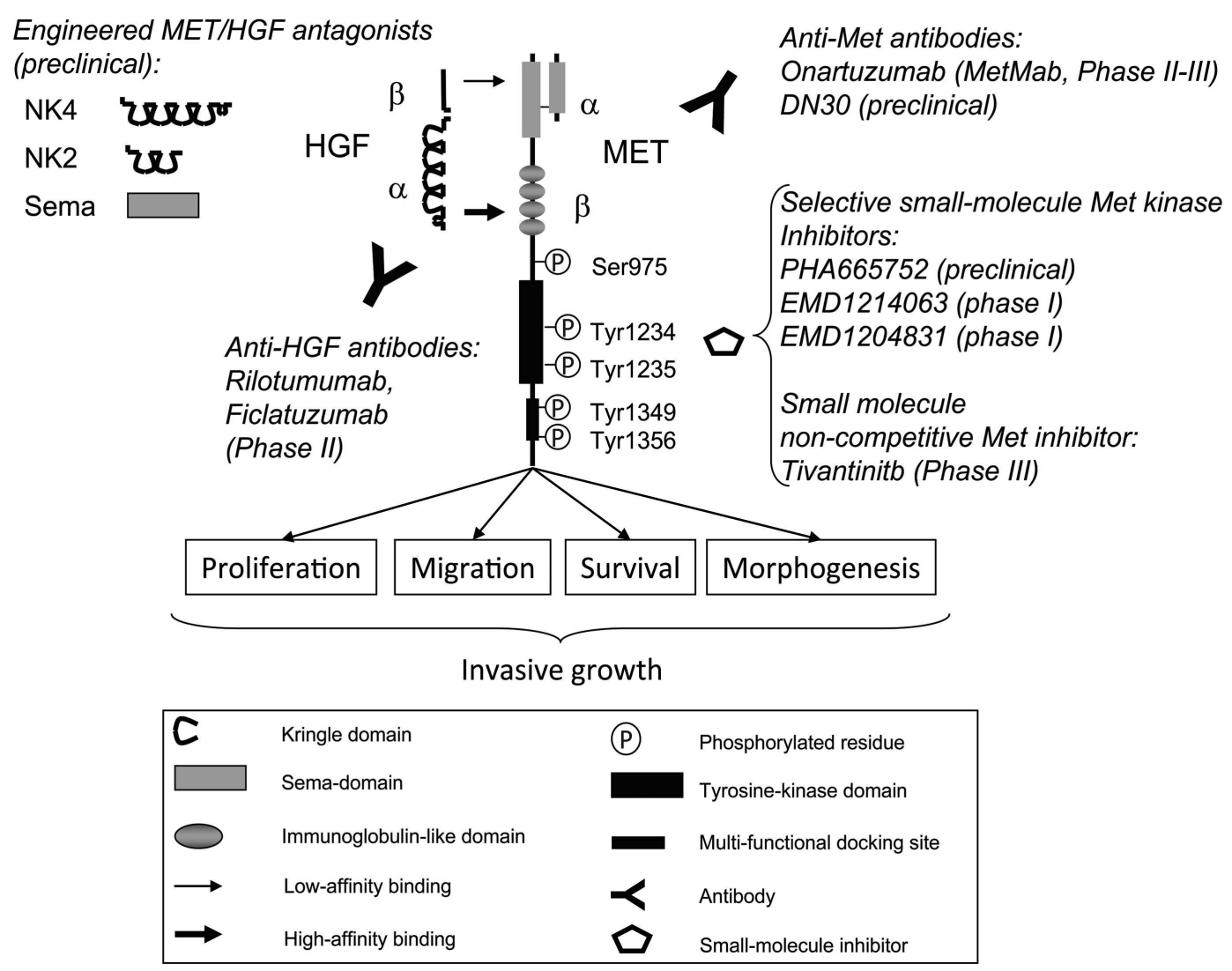

FIGURE 1 | Schematic representation of the receptor tyrosine kinase encoded by the MET oncogene, its ligand HGF, and the main experimental drugs against the receptor or the ligand currently under investigation (engineered MET/HGF antagonists, anti-HGF antibodies, anti-Met antibodies, small-molecule Met inhibitors). The $\alpha$ and $\beta$ chains of both receptor and ligand are represented. In the receptor, the aminoacidic residues undergoing phosphorylation during signal activation are also indicated. For explanation of the specific domain functions, mechanisms of ligand-receptor interaction, and mechanism of action of experimental drugs, see text. the MET cytoplasmic tail to the actin cytoskeleton and, together with Gab1, to sustain activation of the MAP kinase cascade; (ii) $\alpha 6 \beta 4$ integrin, acting as a supplementary docking platform for amplification of PI-3 Kinase, MAP kinase, and SRC-dependent pathways; (iii) B family plexins, the receptors for semaphorins, which can trans-activate MET in the absence of HGF (for a review see Trusolino et al., 2010).

\section{THE MET ONCOGENE IN CANCER}

Inappropriate activation of the MET oncogene has been reported in a wide variety of human tumors, where it supports execution of pathological invasive growth, leading to cancer aggressiveness and metastatic dissemination (Comoglio et al., 2008). MET genetic alterations are relatively rare, and include chromosomal rearrangements, a panel of point mutations, and gene amplification. The chromosomal rearrangement TPR-MET, observed in gastric cancers, results in the expression of a completely intracellular fusion protein that comprises a constitutive dimerization motif and the MET intracellular domain (Soman et al., 1991). Point mutations of MET were found in both hereditary and sporadic papillary renal cancer (Schmidt et al., 1997) and gastric carcinoma (Lee et al., 2000), in childhood liver carcinoma (Park et al., 1999), and lymph node metastases of head and neck squamous carcinoma (Di Renzo et al., 2000). Interestingly, MET point mutations have been recently associated with the so-called "cancers of unknown primary origin" (CUP). These are highly undifferentiated tumors that present at their very onset as metastatic dissemination in the absence of a detectable primary tumor (Stella et al., 2011). MET amplification, resulting in overexpression and constitutive kinase activation, has been found in gastric and esophageal carcinomas (Houldsworth et al., 1990), and medulloblastomas (Tong, 2004). Of special interests is MET amplification emerging in non-small cell lung carcinomas (NSCLC) treated with drugs targeting epidermal growth factor receptor (EGFR; Bean et al., 2007; Engelman et al., 2007). These results provided a rationale for combining EGFR and MET inhibitors in lung cancer clinical trials.

The most frequent cause of constitutive MET activation in human tumors is overexpression of a structurally normal protein, which results from transcriptional upregulation. Indeed, MET transcription can be sustained through mechanisms activated by frequent cancer genetic alterations such as Ras mutation (Ivan et al., 1997), p53 loss (Hwang et al., 2011), or MACC1 expression (Stein et al., 2009). In addition, MET transcription is induced by environmental cues, such as growth factors secreted by the 
adjacent stroma, including HGF itself, or by oxygen deficiency, or hypoxia, a frequent occurrence in the rapidly growing tumor tissue (Pennacchietti et al., 2003). Recently, we have shown that Met transcriptional upregulation, mediated by transcription factor NF-kB, and Met tyrosine kinase activation, leading to cell invasion and protection from apoptosis, occur when cells are exposed to ionizing radiations. Conversely, the use of Met inhibitors sensitizes cells to radiotherapy (De Bacco et al., 2011).

Finally, the discovery that MET protein translation is impaired by miRNA (Migliore et al., 2008), has led to the observation that loss of "tumor suppressor" miRNAs can cause MET overexpression during colorectal cancer progression (Migliore et al., 2012).

\section{STRATEGIES TO TARGET MET}

MET inhibition has been pursued by trying to interfere with each of the main steps controlling MET activation, namely: (i) MET interaction with its ligand HGF; (ii) MET receptor oligomerization; (iii) MET catalytic activity; (iv) MET downstream signaling (for review see Comoglio et al., 2008; Gherardi et al., 2012). These studies have led to formulation of compounds that fall in the following three main classes.

\section{ENGINEERED PROTEINS ANTAGONIZING HGF AND MET}

The complex mechanism of interaction between HGF and MET has been elucidated through structural and crystallographic studies. HGF includes two binding sites for MET: a high-affinity binding site located in the $\alpha$ chain, which binds the MET immunoglobulin-like domains (Basilico et al., 2008), and a lowaffinity binding site located in the $\beta$ chain, which binds the MET sema domain (Stamos et al., 2004; Figure 1). Isolated domains of HGF or MET proteins have been shown to antagonize HGF-MET binding and block the ensuing MET biological effects in preclinical models. The best characterized antagonist is NK4, corresponding to the HGF $\alpha$ chain, and named after the "four kringle" (K) structural motifs (Figure 1). Interestingly, it has been observed that NK4 has a bifunctional role, targeting both the tumor and the microenvironment, as it displays also a powerful anti-angiogenic effect (for a review see Matsumoto and Nakamura, 2008). A similar effect has been reported also for an engineered molecule called "decoy MET," corresponding to the isolated, soluble MET extracellular domain (Michieli et al., 2004). The anti-angiogenic effect of HGF/Met antagonists is explained by the ability of HGF to directly promote endothelial cell growth as well as VEGF expression (for a review see Gherardi et al., 2012). NK4, moreover, can exert an anti-angiogenic effect by mimicking angiostatin (for a review see Matsumoto and Nakamura, 2008). Finally, other engineered protein successfully tested in experimental models as HGF/Met antagonists are: (i) NK2, a naturally occurring splice variant of HGF, including the first two kringle domains (Chan et al., 1991), and (ii) the isolated Sema domain (see above; Kong-Beltran et al., 2004; Figure 1).

\section{ANTIBODIES AGAINST HGF AND MET}

A humanized monoclonal antibody that binds the HGF $\beta$ chain (rilotumumab, or AMG102, developed by Amgen; Figure 1), and inhibits HGF binding to MET, has displayed excellent neutralizing activity in experimental models (Burgess et al., 2006), and is currently tested in several Phase II clinical trials in recurrent glioblastoma, kidney, and gastric carcinoma, and other tumors ${ }^{1}$. Another humanized anti-HGF antibody, currently investigated in Phase II clinical trials for NSCLC, is ficlatuzumab (developed by AVEO; see text footnote 1).

The available antibodies against MET include DN30 (developed by Metheresis; Prat et al., 1998; Petrelli, 2006), and the so-called "METMab" (onartuzumab, developed by Genentech and Roche; Jin et al., 2008; Figure 1). DN30 is a monoclonal antibody that eventually induces proteolytic cleavage and release of the MET extracellular domain (see below). This process causes not only full receptor inhibition, but also ligand neutralization, which results from interaction of the solubilized MET extracellular domain with HGF bound to the extracellular matrix ("decoy effect"). However, on MET binding, DN30 retains a partial agonist activity that has been circumvented by transforming the original IgG divalent form into a monovalent form (Pacchiana, 2010). This antibody is in a preclinical development stage. METMab is a humanized monovalent antibody with neutralizing activity against MET, which, administered in association with EGFR inhibitors to patients affected by NSCLC, has significantly increased the "progressionfree survival" period of patients that expressed high levels of MET (Spigel, 2011).

\section{SMALL MOLECULE MET INHIBITORS}

MET catalytic activity can be blocked by small molecule inhibitors that compete for ATP binding at the kinase active site. A group of these compounds, sharing a common structure (an indolin-2-one core), display specific activity against MET, and include, among the most selective and potent, PHA665752 (Pfizer; Smolen, 2006), EMD1214063, and EMD1204831 (Serono), and JNJ38877605 (Jhonson and Jhonson; De Bacco et al., 2011; Figure 1). These molecules are still in a preclinical or early clinical developmental phase, and, in the case of JNJ38877605, have raised serious concerns for possible human toxicity (for a review see Peters and Adjei, 2012). Another small molecule MET inhibitor, Tivantinib (also known as ARQ197, developed by Arqule), does not compete for ATP binding to the MET catalytic site, and acts through alternative but still poorly characterized mechanisms (Eathiraj et al., 2011; Figure 1). However, it is in advanced stage of clinical development and, in combination with EGFR inhibitors, has shown remarkable activity in extending the progression-free survival of patients with NSCLC (Sequist et al., 2011).

Other inhibitors with broader specificity, concomitantly targeting the tyrosine kinase activity of MET and other receptors, are currently tested in Phase II-III trials. Among the most investigated, Crizotinib (also known as PF-02341066, developed by Pfizer) inhibits MET, ALK, RON, AXL, and TIE2. In phase III trials, Crizotinib has shown a striking activity in NSCLC patients harboring the rare EML4-ALK translocation, leading to expression of a constitutively active ALK kinase (Kwak et al., 2010). Cabozantinib (also known as XL184, developed by Exelixis) inhibits MET, VEGFR2, RET, KIT, FLT3, and TIE2. This compound showed significant activity against a variety of primary and metastatic tumors, among which the most remarkable are metastatic castration-resistant

${ }^{1}$ http://www.vai.org/metclinicaltrials/ 
prostate cancer (Hussain, 2011), and medullary thyroid cancer (Kurzrock et al., 2011). Obviously, in case of broad specificity inhibitors, it is hard to discriminate the contribution of MET inhibition to the overall therapeutical effect.

\section{MET REGULATION BY PROTEASES AND ITS THERAPEUTIC IMPLICATIONS}

Over the past few years the existence of a cross-talk between proteases and tyrosine kinases became increasingly evident (Lopez-Otin and Hunter, 2010). Earlier studies described the ability of MET to activate several proteases, such as Matrixmetalloproteinase-9 (MMP-9; Harvey et al., 2000). The importance of the reverse regulation, i.e., modulation of MET (or other receptor tyrosine kinases) by proteases, became apparent only recently, but proved to be relevant for the development of new cancer therapies (Schelter, 2010; Schelter et al., 2011).

One of the first findings indicating regulation of proteases by MET was that co-expression of MET and HGF increased the metastatic potential of NIH3T3 fibroblasts in vivo, by sustaining constitutive activation of MET signaling and proteolytic activity (Rong et al., 1994). As proteolytic activity is generally considered a prerequisite for metastasis (Deryugina and Quigley, 2006; Fingleton, 2006), several subsequent studies addressed the regulatory effect of MET signaling on pro-invasive proteases. The observation that pro-invasive MMP-9 can be induced by MET signaling (Harvey et al., 2000) is of special interest, as MMP-9, as well as its close relative MMP-2, can cleave collagen type IV, the main component of the basement membrane, a physiological boundary that only fully malignant cells can trespass (Egeblad and Werb, 2002). Beside activation of members of the matrix-metalloproteinase family, it was also shown that MET signaling induces expression and activity of other proteases, including urokinase-type plasminogen activator (uPA) (Jeffers et al., 1996). Taken together, these findings significantly contributed to provide a mechanistic explanation for the pro-invasive effect of HGF, or "invasive growth" (Trusolino and Comoglio, 2002).

It is well known that termination of MET signaling is achieved by down-regulation of this receptor, which occurs after induction of phosphorylation. The canonical process of MET downregulation mostly relies on endocytosis, and seems to be proteaseindependent (for a review see Trusolino et al., 2010). However, there are parallel mechanisms of down-regulation, which are indeed protease-dependent. One mechanism was found in apoptotic cells, where MET is cleaved by caspases, resulting in blockage of MET-mediated survival signals (Foveau et al., 2007). This process could be inactivated in cancer cells, which are often unable to unleash the apoptotic pathway, leading to MET accumulation, and further support of anti-apoptotic signals.

A second mechanism of protease-dependent MET downregulation involves extracellular proteases. We previously reported that, in a murine model, elevated levels of systemic Tissue Inhibitor of Metalloprotease-1 (TIMP-1) promoted metastatic dissemination of tumor cells to the liver. This effect was dependent on increased activity of the MET signaling pathway in the liver tissue microenvironment (Kopitz et al., 2007). This observation suggested the hypothesis that the endogenous broad spectrum inhibitor TIMP-1 inhibited a potential MET sheddase, causing accumulation of MET on the cell surface, and hyperactivation of MET signaling (Kopitz et al., 2007). Earlier reports (Nath et al., 2001; Lee et al., 2002) had shown that, under physiological conditions, MET shedding was mediated by a protease sensitive to tissue inhibitor of metalloproteinases-3 (TIMP-3), thus likely belonging to "A Disintegrin And Metalloproteinase (ADAM)" family, which includes prominent mediators of cell surface protein shedding (Murphy, 2008). In particular, it was known that TIMP-3 can inhibit ADAM-10 and ADAM-17, whereas TIMP-1 can only inhibit ADAM-10 (Amour et al., 1998, 2000). In our attempt to explain the pro-metastatic effect of TIMP-1, mediated by MET accumulation, we obtained the first evidence that ADAM-10 is a MET sheddase (Kopitz et al., 2007), a finding further confirmed by other studies (Schirrmeister et al., 2009; Schelter, 2010; Doberstein et al., 2011; Schelter et al., 2011). Moreover, also ADAM-17, a close functional homolog of ADAM-10, was identified as a potential MET sheddase (Foveau et al., 2009). Taken together, these findings explain the early observation that MET shedding can rely on TIMP-3-sensitive proteases, as both ADAM-10 and ADAM-17 are inhibited by TIMP-3 (Amour et al., 1998, 2000). We concluded that, in the liver microenvironment, elevated levels of TIMP-1 inhibited MET shedding in liver cells, leading to MET accumulation and increased signaling, thereby providing a fertile soil for colonization by metastatic cells (host effect; Kopitz et al., 2007). Moreover, we showed that inhibition of MET shedding by TIMP-1 occurs also in cancer cells, thus sustaining their invasive growth potential and ability to colonize the liver (Schelter et al., 2011).

Taken together, these studies show that regulation of MET signaling by proteases is relevant in the context of cancer. Therefore, the question arises whether this mechanism can be exploited to develop anti-cancer therapies. Previously, it was shown that a MET-specific monoclonal antibody (DN30) induces shedding of MET and inhibition of MET signaling (Petrelli, 2006), strongly suggesting the involvement of an ADAM protease in the antibody's mechanism of action. Indeed we recently showed that ADAM-10 (but not ADAM-17) mediated MET shedding induced by $\mathrm{DN} 30$, and thus it was critical for the therapeutic effect of this antibody (Schelter, 2010). Knockdown of ADAM-10, but not of ADAM-17, abolished MET down-regulation in different tumor cell lines, and compromised the DN30 ability to block MET signaling (Schelter, 2010). Moreover, also the DN30 ability to inhibit HGF-dependent tumor cell scattering and invasiveness in vitro was shown to depend on ADAM-10 (Schelter, 2010). These findings led to the conclusion that patients should be screened for ADAM-10 expression before being treated with DN30, as ADAM10 is required for the activity of this antibody. Furthermore, these observations suggest the possibility to finely tune the specificity of targeted therapies, such as the DN30 antibody, by combining the activity of the antibody and the protease required for its activity.

\section{CONCLUSION}

The tyrosine kinase receptor encoded by the MET oncogene is expressed in a wide variety of tumors, where it often displays a deregulated activity that leads to pathological "invasive growth," featuring invasion, and metastasis. Moreover, MET is expressed by endothelial cells, and can be involved in tumor angiogenesis. The connection between MET and tumor microenvironment 
is emphasized by the interplay with matrix proteases, such as ADAM-10, that modulate its activity. Overall, MET hyperactivation is likely to play a crucial role in tumor onset and progression. MET and its ligand HGF are attractive pharmacological targets: the ligand and the receptor extracellular domain can be blocked by antibodies, or by engineered protein antagonists, while the tyrosine kinase activity can be inhibited by small molecules. Antibodies and kinase inhibitors are currently tested in clinical trials with encouraging results.

\section{REFERENCES}

Amour, A., Knight, C. G., Webster, A., Slocombe, P. M., Stephens, P. E., Knauper, V., Docherty, A. J., and Murphy, G. (2000). The in vitro activity of ADAM-10 is inhibited by TIMP-1 and TIMP-3. FEBS Lett. 473, 275-279.

Amour, A., Slocombe, P. M., Webster, A., Butler, M., Knight, C. G., Smith, B. J., Stephens, P. E., Shelley, C., Hutton, M., Knauper, V., Docherty, A. J., and Murphy, G. (1998). TNF-alpha converting enzyme (TACE) is inhibited by TIMP-3. FEBS Lett. 435, 39-44.

Basilico, C., Arnesano, A., Galluzzo, M., Comoglio, P. M., and Michieli, P. (2008). A high affinity hepatocyte growth factor-binding site in the immunoglobulin-like region of Met. J. Biol. Chem. 283, 21267-21277.

Bean, J., Brennan, C., Shih, J. Y., Riely, G., Viale, A., Wang, L., Chitale, D., Motoi, N., Szoke, J., Broderick, S., Balak, M., Chang, W. C., Yu, C. J., Gazdar, A., Pass, H., Rusch, V., Gerald, W., Huang, S. F., Yang, P. C., Miller, V., Ladanyi, M., Yang, C. H., and Pao, W. (2007). MET amplification occurs with or without T790M mutations in EGFR mutant lung tumors with acquired resistance to gefitinib or erlotinib. Proc Natl. Acad. Sci. U.S.A. 104, 20932-20937.

Birchmeier, C., and Gherardi, E. (1998). Developmental roles of $\mathrm{HGF} / \mathrm{SF}$ and its receptor, the c-Met tyrosine kinase. Trends Cell Biol. 8, 404-410.

Boccaccio, C., and Comoglio, P. M. (2006). Invasive growth: a METdriven genetic programme for cancer and stem cells. Nat. Rev. Cancer 6, 637-645.

Burgess, T., Coxon, A., Meyer, S., Sun, J., Rex, K., Tsuruda, T., Chen, Q., Ho, S. Y., Li, L., Kaufman, S., McDorman, K., Cattley, R. C., Sun, J., Elliott, G., Zhang, K., Feng, X., Jia, X. C., Green, L., Radinsky, R., and Kendall, R. (2006). Fully human monoclonal antibodies to hepatocyte growth factor with therapeutic potential against hepatocyte growth factor/c-Met-dependent human tumors. Cancer Res. 66, 1721-1729.
Chan, A. M., Rubin, J. S., Bottaro, D. P., Hirschfield, D. W., Chedid, M., and Aaronson, S. A. (1991). Identification of a competitive HGF antagonist encoded by an alternative transcript. Science 254, 1382-1385.

Comoglio, P. M., Giordano, S., and Trusolino, L. (2008). Drug development of MET inhibitors: targeting oncogene addiction and expedience. Nat. Rev. Drug Discov. 7, 504-516.

De Bacco, F., Luraghi, P., Medico, E., Reato, G., Girolami, F., Perera, T., Gabriele, P., Comoglio, P. M., and Boccaccio, C. (2011). Induction of MET by ionizing radiation and its role in radioresistance and invasive growth of cancer. J. Natl. Cancer Inst.

Deryugina, E. I., and Quigley, J. P. (2006). Matrix metalloproteinases and tumor metastasis. Cancer Metastasis Rev. 25, 9-34.

Di Renzo, M. F., Olivero, M., Martone, T., Maffe, A., Maggiora, P., Stefani, A. D., Valente, G., Giordano, S., Cortesina, G., and Comoglio, P. M. (2000). Somatic mutations of the MET oncogene are selected during metastatic spread of human HNSC carcinomas. Oncogene 19, 1547-1555. Gutwein, P. (2011). The transcription factor PAX2 regulates ADAM10 expression in renal cell carcinoma. Carcinogenesis 32, 1713-1723.

Eathiraj, S., Palma, R., Volckova, E., Hirschi, M., France, D. S., Ashwell, M. A., and Chan, T. C. (2011). Discovery of a novel mode of protein kinase inhibition characterized by the mechanism of inhibition of human mesenchymal-epithelial transition factor (c-Met) protein autophosphorylation by ARQ 197. J. Biol. Chem. 286, 20666-20676. functions for the matrix metalloproteinases in cancer progression. Nat. Rev. Cancer 2, 161-174.

Engelman, J. A., Zejnullahu, K., Mitsudomi, T., Song, Y., Hyland, C., Park, J. O., Lindeman, N., Gale, C. M., Zhao, X., Christensen, J., Kosaka, T., Holmes, A. J., Rogers, A. M., Cappuzzo, F., Mok, T., Lee, C., Johnson, 103, 645-661.

Doberstein, K., Pfeilschifter, J., and

Egeblad, M., and Werb, Z. (2002). New

\section{ACKNOWLEDGMENTS}

We thank Paolo M. Comoglio for critical discussion. This work was supported by the European Community's Seventh Framework Programme FP7/2007-2011 under grant agreement no 201279 (Microenvironment and metastasis), by AIRC - Special Program Molecular Clinical Oncology 5xMille, N. 9970 (to Carla Boccaccio), Regione Piemonte PI-STEM (to Carla Boccaccio), KR2047/11, and KR2047/1-2 of the Deutsche Forschungsgemeinschaft (to Achim Krüger).

B. E., Cantley, L. C., and Janne, P. A. (2007). MET amplification leads to gefitinib resistance in lung cancer by activating ERBB3 signaling. Science 316, 1039-1043.

Fingleton, B. (2006). Matrix metalloproteinases: roles in cancer and metastasis. Front. Biosci. 11, 479-491.

Foveau, B., Ancot, F., Leroy, C., Petrelli, A., Reiss, K., Vingtdeux, V., Giordano, S., Fafeur, V., and Tulasne, D. (2009). Down-regulation of the met receptor tyrosine kinase by presenilin-dependent regulated intramembrane proteolysis. Mol. Biol. Cell 20, 2495-2507.

Foveau, B., Leroy, C., Ancot, F., Deheuninck, J., Ji, Z., Fafeur, V., and Tulasne, D. (2007). Amplification of apoptosis through sequential caspase cleavage of the MET tyrosine kinase receptor. Cell Death Differ. 14, 752-764.

Gherardi, E., Birchmeier, W., Birchmeier, C., and Vande, W. G. (2012). Targeting MET in cancer: rationale and progress. Nat. Rev. Cancer 12, 89-103.

Gherardi, E., Youles, M. E., Miguel, R. N., Blundell, T. L., Iamele, L., Gough, J., Bandyopadhyay, A., Hartmann, G., and Butler, P. J. (2003). Functional map and domain structure of MET, the product of the c-met protooncogene and receptor for hepatocyte growth factor/scatter factor. Proc. Natl. Acad. Sci. U.S.A. 100, 12039-12044.

Giordano, S., Ponzetto, C., Di Renzo, M. F., Cooper, C. S., and Comoglio, P. M. (1989). Tyrosine kinase receptor indistinguishable from the c-met protein. Nature 339, 155-156.

Harvey, P., Clark, I. M., Jaurand, M. C., Warn, R. M., and Edwards, D. R. (2000). Hepatocyte growth factor/scatter factor enhances the invasion of mesothelioma cell lines and the expression of matrix metalloproteinases. Br. J. Cancer 83, 1147-1153.

Houldsworth, J., Cordon-Cardo, C., Ladanyi, M., Kelsen, D. P., and Chaganti, R. S. (1990). Gene amplification in gastric and esophageal adenocarcinomas. Cancer Res. 50, 6417-6422.
Hussain, M. (2011). Cabozantinib (XL184) in metastatic castrationresistant prostate cancer (mCRPC): results from a phase II randomized discontinuation trial. J. Clin. Oncol. $29,4516$.

Hwang, C. I., Matoso, A., Corney, D. C., Flesken-Nikitin, A., Korner, S., Wang, W., Boccaccio, C., Thorgeirsson, S. S., Comoglio, P. M., Hermeking, H., and Nikitin, A. Y. (2011). Wild-type p53 controls cell motility and invasion by dual regulation of MET expression. Proc Natl. Acad. Sci. U.S.A. 108, 14240-14245.

Ivan, M., Bond, J. A., Prat, M., Comoglio, P. M., and Wynford-Thomas, D. (1997). Activated ras and ret oncogenes induce over-expression of c-met (hepatocyte growth factor receptor) in human thyroid epithelial cells. Oncogene 14, 2417-2423.

Jeffers, M., Rong, S., and Vande, W. G. (1996). Enhanced tumorigenicity and invasion-metastasis by hepatocyte growth factor/scatter factor-met signalling in human cells concomitant with induction of the urokinase proteolysis network. Mol. Cell. Biol. 16, 1115-1125.

Jin, H., Yang, R., Zheng, Z., Romero, M., Ross, J., Bou-Reslan, H., Carano, R. A., Kasman, I., Mai, E., Young, J., Zha, J., Zhang, Z., Ross, S., Schwall, R., Colbern, G., and Merchant, M. (2008). MetMAb, the one-armed 5D5 anti-c-Met antibody, inhibits orthotopic pancreatic tumor growth and improves survival. Cancer Res. 68, 4360-4368.

Kong-Beltran, M., Stamos, J., and Wickramasinghe, D. (2004). The Sema domain of Met is necessary for receptor dimerization and activation. Cancer Cell 6, 75-84.

Kopitz, C., Gerg, M., Bandapalli, O. R., Ister, D., Pennington, C. J., Hauser, S., Flechsig, C., Krell, H. W., Antolovic, D., Brew, K., Nagase, H., Stangl, M., von Weyhern, C. W., Brucher, B. L., Brand, K., Coussens, L. M., Edwards, D. R., and Kruger, A. (2007). Tissue inhibitor of metalloproteinases1 promotes liver metastasis by induction of hepatocyte growth factor signaling. Cancer Res. 67, 8615-8623. 
Kurzrock, R., Sherman, S. I., Ball, D. W., Forastiere, A. A., Cohen, R. B., Mehra, R., Pfister, D. G., Cohen, E. E., Janisch, L., Nauling, F., Hong, D. S., Ng, C. S., Ye, L., Gagel, R. F., Frye, J., Muller, T., Ratain, M. J., and Salgia, R. (2011). Activity of XL184 (Cabozantinib), an oral tyrosine kinase inhibitor, in patients with medullary thyroid cancer. J. Clin. Oncol. 29, 2660-2666.

Kwak, E. L., Bang, Y. J., Camidge, D. R., Shaw, A. T., Solomon, B., Maki, R. G., Ou, S. H., Dezube, B. J., Janne, P. A., Costa, D. B., Varella-Garcia, M., Kim, W. H., Lynch, T. J., Fidias, P., Stubbs, H., Engelman, J. A., Sequist, L. V., Tan, W., Gandhi, L., MinoKenudson, M., Wei, G. C., Shreeve, S. M., Ratain, M. J., Settleman, J., Christensen, J. G., Haber, D. A., Wilner, K., Salgia, R., Shapiro, G. I., Clark, J. W., and Iafrate, A. J. (2010). Anaplastic lymphoma kinase inhibition in non-small-cell lung cancer. $N$. Engl. J. Med. 363, 1693-1703.

Lee, J. H., Han, S. U., Cho, H., Jennings, B., Gerrard, B., Dean, M., Schmidt, L., Zbar, B., and Vande Woude, G. F. (2000). A novel germ line juxtamembrane Met mutation in human gastric cancer. Oncogene 19, 4947-4953.

Lee, M. H., Verma, V., Maskos, K., Nath, D., Knauper, V., Dodds, P., Amour, A., and Murphy, G. (2002). Engineering $\mathrm{N}$-terminal domain of tissue inhibitor of metalloproteinase (TIMP)-3 to be a better inhibitor against tumour necrosis factoralpha-converting enzyme. Biochem. J. 364, 227-234.

Lopez-Otin, C., and Hunter, T. (2010). The regulatory crosstalk between kinases and proteases in cancer. Nat. Rev. Cancer 10, 278-292.

Matsumoto, K., and Nakamura, T. (2008). NK4 gene therapy targeting HGF-Met and angiogenesis. Front. Biosci. 13, 1943-1951.

Michieli, P., Mazzone, M., Basilico, C., Cavassa, S., Sottile, A., Naldini, L., and Comoglio, P. M. (2004). Targeting the tumor and its microenviroment by a dual-function decoy Met receptor. Cancer Cell 6, 61-73.

Migliore, C., Martin, V., Leoni, V. P., Restivo, A., Atzori, L., Petrelli, A., Isella, C., Zorcolo, L., Sarotto, I., Casula, G., Comoglio, P. M., Columbano, A., and Giordano, S. (2012). MiR-1 downregulation cooperates with MACC1 in promoting MET overexpression in human colon cancer. Clin. Cancer Res. 18, 737-747.

Migliore, C., Petrelli, A., Ghiso, E., Corso, S., Capparuccia, L., Eramo,
A., Comoglio, P. M., and Giordano, S. (2008). MicroRNAs impair MET-mediated invasive growth. Cancer Res. 68, 10128-10136.

Murphy, G. (2008). The ADAMs: signalling scissors in the tumour microenvironment. Nat. Rev. Cancer 8, 929-941.

Naldini, L., Weidner, K. M., Vigna, E., Gaudino, G., Bardelli, A., Ponzetto, C., Narsimhan, R. P., Hartmann, G., Zarnegar, R., and Michalopoulos, G. K. (1991). Scatter factor and hepatocyte growth factor are indistinguishable ligands for the MET receptor. EMBO J. 10, 2867-2878.

Nath, D., Williamson, N. J., Jarvis, R., and Murphy, G. (2001). Shedding of c-Met is regulated by crosstalk between a G-protein coupled receptor and the EGF receptor and is mediated by a TIMP-3 sensitive metalloproteinase. J. Cell Sci. 114, 1213-1220.

Pacchiana, G. (2010). Monovalency unleashes the full therapeutic potential of the DN-30 anti-Met antibody. J. Biol. Chem. 285, 36149-36157.

Park, W. S., Dong, S. M., Kim, S. Y., Na, E. Y., Shin, M. S., Pi, J. H., Kim, B. J., Bae, J. H., Hong, Y. K., Lee, K. S. Lee, S. H., Yoo, N. J., Jang, J. J., Pack, S., Zhuang, Z., Schmidt, L., Zbar, B., and Lee, J. Y. (1999). Somatic mutations in the kinase domain of the Met/hepatocyte growth factor receptor gene in childhood hepatocellular carcinomas. Cancer Res. 59, 307-310.

Pennacchietti, S., Michieli, P., Galluzzo, M., Mazzone, M., Giordano, S., and Comoglio, P. M. (2003). Hypoxia promotes invasive growth by transcriptional activation of the met protooncogene. Cancer Cell 3, 347-361.

Peters, S., and Adjei, A. A. (2012). MET: a promising anticancer therapeutic target. Nat. Rev. Clin. Oncol. 9, 314-326.

Petrelli, A. (2006). Ab-induced ectodomain shedding mediates hepatocyte growth factor receptor down-regulation and hampers biological activity. Proc. Natl. Acad. Sci. U.S.A. 103, 5090-5095.

Prat, M., Crepaldi, T., Pennacchietti, S., Bussolino, F., and Comoglio, P. M. (1998). Agonistic monoclonal antibodies against the Met receptor dissect the biological responses to HGF. J. Cell Sci. 111, 237-247.

Rong, S., Segal, S., Anver, M., Resau, J. H., and Vande Woude, G. F. (1994). Invasiveness and metastasis of NIH 3T3 cells induced by Met-hepatocyte growth factor/scatter factor autocrine stimulation. Proc. Natl. Acad. Sci. U.S.A. 91, 4731-4735.

Schelter, F. (2010). A disintegrin and metalloproteinase-10 (ADAM-10) mediates DN30 antibody-induced shedding of the met surface receptor. J. Biol. Chem. 285, 26335-26340.

Schelter, F., Grandl, M., Seubert, B. Schaten, S., Hauser, S., Gerg, M. Boccaccio, C., Comoglio, P., and Kruger, A. (2011). Tumor cellderived Timp-1 is necessary for maintaining metastasis-promoting Met-signaling via inhibition of Adam-10. Clin. Exp. Metastasis 28 793-802.

Schirrmeister, W., Gnad, T., Wex, T., Higashiyama, S., Wolke, C., Naumann, M., and Lendeckel, U. (2009). Ectodomain shedding of E-cadherin and c-Met is induced by Helicobacter pylori infection. Exp. Cell Res. 315 3500-3508.

Schmidt, L., Duh, F. M., Chen, F., Kishida, T., Glenn, G., Choyke, P. Scherer, S. W., Zhuang, Z., Lubensky, I., Dean, M., Allikmets, R., Chidambaram, A., Bergerheim, U. R., Feltis, J. T., Casadevall, C., Zamarron, A., Bernues, M., Richard, S., Lips, C. J., Walther, M. M., Tsui, L. C. Geil, L., Orcutt, M. L., Stackhouse, T. and Zbar, B. (1997). Germline and somatic mutations in the tyrosine kinase domain of the MET protooncogene in papillary renal carcinomas. Nat. Genet. 16, 68-73.

Sequist, L. V., von, P. J., Garmey, E. G., Akerley, W. L., Brugger, W., Ferrari, D., Chen, Y., Costa, D. B., Gerber D. E., Orlov, S., Ramlau, R., Arthur, S., Gorbachevsky, I., Schwartz, B. and Schiller, J. H. (2011). Randomized phase II study of erlotinib plus tivantinib versus erlotinib plus placebo in previously treated nonsmall-cell lung cancer. J. Clin. Oncol. 29, 3307-3315.

Smolen, G. A. (2006). Amplification of MET may identify a subset of cancers with extreme sensitivity to the selective tyrosine kinase inhibitor PHA665752. Proc. Natl. Acad. Sci. U.S.A. 103, 2316-2321.

Soman, N. R., Correa, P., Ruiz, B. A., and Wogan, G. N. (1991). The TPR-MET oncogenic rearrangement is present and expressed in human gastric carcinoma and precursor lesions. Proc. Natl. Acad. Sci. U.S.A. 88, 4892-4896.

Spigel, D. R. (2011). Final efficacy results from OAM4558g, a randomized phase II study evaluating MetMAb or placebo in combination with erlotinib in advanced NSCLC. J. Clin. Oncol. 29, abstr. 7505.
Stamos, J., Lazarus, R. A., Yao, X., Kirchhofer, D., and Wiesmann, C. (2004). Crystal structure of the HGF beta-chain in complex with the sema domain of the Met receptor. EMBO J. 23, 2325-2335.

Stein, U., Walther, W., Arlt, F., Schwabe, H., Smith, J., Fichtner, I., Birchmeier, W., and Schlag, P. M. (2009). MACC1, a newly identified key regulator of HGF-MET signaling, predicts colon cancer metastasis. Nat. Med. 15, 59-67.

Stella, G. M., Benvenuti, S., Gramaglia, D., Scarpa, A., Tomezzoli, A., Cassoni, P., Senetta, R., Venesio, T., Pozzi, E., Bardelli, A., and Comoglio, P. M. (2011). MET mutations in cancers of unknown primary origin (CUPs). Hum. Mutat. 32, 44-50.

Tong, C. Y. (2004). Detection of oncogene amplifications in medulloblastomas by comparative genomic hybridization and array-based comparative genomic hybridization. J. Neurosurg. 100, 187-193.

Trusolino, L., Bertotti, A., and Comoglio, P. M. (2010). MET signalling: principles and functions in development, organ regeneration and cancer. Nat. Rev. Mol. Cell Biol. $11,834-848$.

Trusolino, L., and Comoglio, P. M. (2002). Scatter-factor and semaphorin receptors: cell signalling for invasive growth. Nat. Rev. Cancer 2, 289-300.

Conflict of Interest Statement: The authors declare that the research was conducted in the absence of any commercial or financial relationships that could be construed as a potential conflict of interest.

Received: 08 June 2012; paper pending published: 08 July 2012; accepted: 21 August 2012; published online: 11 September 2012.

Citation: Luraghi P, Schelter F, Krüger A and Boccaccio C (2012) The MET oncogene as a therapeutical target in cancer invasive growth. Front. Pharmacol. 3:164. doi: 10.3389/fphar.2012.00164

This article was submitted to Frontiers in Pharmacology of Anti-Cancer Drugs, a specialty of Frontiers in Pharmacology. Copyright () 2012 Luraghi, Schelter, Krüger and Boccaccio. This is an openaccess article distributed under the terms of the Creative Commons Attribution License, which permits use, distribution and reproduction in other forums, provided the original authors and source are credited and subject to any copyright notices concerning any third-party graphics etc. 